\title{
Effect of genotype, sex and parity on growth traits of diallel crossed Nigerian indigenous and exotic pigs
}

Okoro $^{1}$, V. M. O. Ogundu ${ }^{1}$, U. E. Udedibie ${ }^{1}$., A. B. I., Okoro ${ }^{2}$., C. L., Ukwu ${ }^{3}$, H. O. and $\mathrm{Ibe}^{4}, \mathrm{~S} . \mathrm{N}$.

${ }^{1}$ Department of Animal Science and Technology, Federal University of Technology, Owerri. ${ }^{2}$ Department of Agriculture, Owerri Municipal Council, Owerri. ${ }^{3}$ Department of Animal Breeding and Physiology, College of Animal science, University of Agriculture Makurdi, P.M.B. 7267 Makurdi, Benue State, Nigeria. ${ }^{4}$ Department of Animal Breeding and Genetics, Michael Okpara University of Agriculture, Umudike.

Corresponding author: melavicong@gmail.com

\begin{abstract}
Three breeds of pig namely; Indigenous (IN), Large white (LW) and Landrace (LR) breeds were crossed in full diallel arrangement to evaluate the effects of cross, sex and parity on growth traits as well as establish the nature of gene action due to the growth traits at birth, weaning and 20 weeks of age. Each line crossed in a full $3 \times 3$ diallel cross resulted in a total of 132, 107 and 105 pigs at birth, weaning and 20 weeks of age respectively. General Combining Ability (GCA), Specific Combining Ability (SCA) and Reciprocal Effects (RE) were estimated for eight traits which includes Body weight (BWT), Ear length (EL), Tail length (TL), Heart girth (HG), Snout circumference (SC), Snout length (SL), Height at wither $(H W)$ and Body length $(B L)$. There were significant differences $(P<0.05)$ among the various crosses, sex and parity but no significant interaction. The LRxLW cross consistently expressed higher body weight and morphometric traits than other crosses at birth, weaning and 20 weeks of age, while the INxIN expressed least body weight at birth and 20 weeks of age, while LWxIN was the least at weaning. There was no significant $G C A$ effect $(P>0.05)$ on all the traits measured, but $S C A$ was significant $(P<0.01)$ for all morphometric traits and body weight. RE was significant for body weight at birth and weaning, while at 20 weeks, was significant for SC and HW. The non-significant GCA estimates along with significant $S C A$ estimates suggest that the genes governing the eight traits measured do not act additively, but non-additively, implying that improvement of those traits may be attained by exploiting heterosis through planned crossbreeding. However, the significant reciprocal effect in body weight and some morphometric traits indicates maternal and sex-linked effect at the affected ages, implying that significant reciprocal cross may be used to attain high performance for the growth traits in the progeny.
\end{abstract}

Key words: DialleI cross, General combining ability, Specific combining ability, Reciprocal effects, Indigenous pigs, Growth traits.

\section{Introduction}

Swine breeding and genetics has advanced tremendously utilizing crossbreeding techniques in order to exploit heterosis. Heterosis is the difference between crossbred animals and the average of their purebred counterparts (Ibe, 1998). With general use of breed and strain crossing in current swine production, it is important to estimate basic parameter values with which to evaluate and identify superior crossing combinations. The results of most 
crossbreeding work have in general shown an advantage in the performance of crosses over that of their parents; however, literature concerning the general and specific combining abilities of lines is not extensive. Combining ability, as used by animal and plant breeders, is divided into general and specific combining ability. General combining ability (GCA) is a measure of the average performance of a line in hybrid combination, while specific combining ability (SCA) refers to specific crosses that do better or worse than would be expected based on the average performance of the lines involved (Carmon, 1976). One of the studies that support the idea that breeds have different behaviour when used in crosses was presented by Schneider (1976), in studies involving Landrace and Poland China crosses. These results indicated that crossbred animals were superior to purebred animals in number of live piglets, vigour of offsprings at birth, survival from birth to weaning and litter weight at weaning.

Desirable characteristics of different breeds can be utilized if some breeds can be identified as good maternal breeds and others as good paternal breeds (Buchanan et al., 2005). Okoro et al. (2012a) had earlier reported a significantly better performance of black turkey sire genotype in cross with white dam genotype as paternal breed than bronze genotype. The diallel cross is commonly used in plant and animal breeding in evaluating the genetic structure of a population of pure-bred lines. An accurate analysis of this mating design is therefore not only of theoretical but also of practical economic importance and has been dealt with by many authors (e.g. Eisen et al., 1983; Virk et al., 1985; Okoro et al., 2012a). A common assumption underlying most analyses of the diallel cross is the absence of any reciprocal differences, which are primarily caused by sex-linkage and maternal effects. Although the effects of such differences on the analysis of diallel crosses have been examined by Wearden (1964), Durrant (1965), Eisen et al. (1966), Topham (1966), and Mather and Jinks (1982), these investigators were primarily concerned with testing the significance of possible effects and with determining the probable cause of reciprocal effects. Although reciprocal cross is of crossbreeding fundamental, there is a dearth of information on the effect of GCA, SCA and reciprocal effects on crosses involving local pigs of the tropical rainforest region especially of SouthEastern Nigeria.

This experiment therefore, was conducted to investigate the effect of cross, parity, sex and their interactions on growth traits, as well as evaluate the additive and nonadditive genetic effects on growth traits in crosses of Indigenous pigs of South-eastern Nigeria and their exotic counterparts.

\section{Material and Methods}

\section{Studylocation}

This research was carried out at the piggery unit of the Federal University of Technology Teaching and Research Farm. The mean annual rainfall is $2500 \mathrm{~mm}$, temperature ranges from 26.5 to $27.5^{\circ} \mathrm{C}$, and humidity ranges from 70 to $80 \%$. This research was conducted between March 2009 and September 2012.

Management of parent stock and experimental animals

The parent animals were fed concentrates containing $17 \%$ crude protein (CP) and $2,480 \mathrm{Kcal} / \mathrm{kg}$ energy. A compounded feed containing $24 \% \mathrm{CP}$ and $2,500 \mathrm{Kcal} / \mathrm{kg}$ energy was also used to flush the sows before mating in order to increase the litter 
size and provide enough nutrients for embryonic and foetal development.

Prior to mating the animals, the barrows and gilts were placed in separate pens, until heat was detected in the gilts the second time because at first heat, they were not mated until the second detected heat. Females were taken to the boar according to the mating design culminating to two parities per cross for main and reciprocal crosses. For the inseminated groups (WAI x LW, WAI $x$ LR, LR x WAI and LW x WAI), semen were harvested, processed using cheese cloths to separate the gelatinous fraction and inseminated using pig catheters within the same day of collection.

After mating/insemination, the sows were removed from the pen to their individual pens. On confirmation of pregnancy, the ingilts were kept in pairs until about 14 days to parturition; before been moved to farrowing pens until parturition occurs. At this time, quantity of their diet was increased up to $4.0 \mathrm{~kg}$ per sow feed with fresh clean water provided. After parturition, the live piglets were retained with their dams to suckle the colostrum while still birth and dead ones were later examined and parameters taken before they were buried. Wood shavings were provided as litter materials for insulation. The dams were given antibiotics of $2 \mathrm{mls}$ volume in order to reduce bacterial load to the suckling piglets, while the piglets were given iron injection to prevent piglet anaemia two days after birth. Records on birth weight and morphometric traits were taken. Notching of the piglets, for identification was done seven days after parturition and weaning was done at nine weeks of age. Piglets were weaned and provided high-protein diet (starter ration) from four weeks post birth, while ivomectin was also administered to those with skin infections. At weaning, they were dewormed before putting them in the grower pens. They were fed and measurements taken until maturity age of 20 weeks.

\section{Mating design and data collection}

A full diallel cross comprising three breeds (Nigerian Indigenous, Large white and Landrace) of pigs made up of 5 sires per breed and 10 dams per breed was conducted, and a total of 132 offsprings were generated at birth (Table 1). The method of identification was through the use of ear notching. Each individual (offspring) was identified based on the family ear notching area.

The animals were housed under intensive system of with dwarf walls and asbestors with all routine medications given at the appropriate time. The linear body measurements and body weight were taken on weekly basis. The parameters taken in linear body measurements include the Ear length (EL), Tail length (TL), Heart girth (HG), Snout circumference (SC), Snout length (SL), Height at wither (HW) and Body length (BL). The linear body measurements were taken using the measuring tape, while the live body weight (BWT) was measured using a weighing scale.

\section{Statistical analysis}

Data obtained was first subjected to analysis of variance, to test the null hypothesis that there were no significant differences among the crosses, sex, parity and their interactions. The GLM procedure of SAS (1999) was used to conduct the analysis of variance and where significant differences was established among the crosses, sex and parity, Student-NewmanKeuls multiple range test according to SAS (1999) was used to separate the means. The method of Griffing (1956), according to Siewerdt and Dionello (1991) was further 
Effect of genotype and parity on growth traits of diallel crossed indigenous and exotic pigs

Table 1: Number of pigs produced by Sire and Dam lines at birth

\begin{tabular}{l|lll}
\hline \multirow{2}{*}{ Sire lines } & \multicolumn{3}{|c}{ Dam lines } \\
\cline { 2 - 4 } & IN & LW & LR \\
\hline IN & 10 & 9 & 11 \\
LW & 12 & 26 & 15 \\
LR & 11 & 14 & 24 \\
\hline
\end{tabular}

used to examine the diallel cross using the statistical model for combining abilities:

$Y_{i j}=\mu+g_{i}+g_{j}+s_{i j}+r_{i j}+{ }^{1 /} n_{i j p 2} \sum_{c i j k}$

Where,

$Y_{i j}=$ Mean of $i j^{\text {th }}$ cross between line I (as sire) and line $\mathrm{j}$ (as dam)

$\mu=$ Overall mean

$\mathrm{g} / \mathrm{g}_{\mathrm{j}}=$ General combining ability $(\mathrm{GCA})$ of the $\mathrm{i}^{\mathrm{th}} / \mathrm{j}^{\text {th }}$ breed

$\mathrm{s}_{\mathrm{ij}}=$ Specific combining ability (SCA) of the $\mathrm{ij}^{\text {th }}$ combination

$r_{i j}=$ Reciprocal effect (RE)

$\mathrm{n}_{\mathrm{ij}}=$ Number of individuals produced from $\mathrm{i}^{\text {th }}$ and $\mathrm{j}^{\text {th }}$ parental cross

$\mathrm{p}=$ Number of strains used in the cross

$\mathrm{e}_{\mathrm{ijk}}=$ Error associated with $\mathrm{k}^{\text {th }}$ individual observation from the $i^{\text {th }}$ and $j^{\text {th }}$ crosses.

The mean squares for GCA, SCA and RE were generated using the methods given by Siewerdt and Dionello, (1991) according to Okoro et al. (2012a). Values of GCA, SCA and $\mathrm{RE}$ were computed using the expressions given by Obasi and Ibe (2008).

\section{Results and Discussion}

Effect of genetic groups, sex and parity

The least square means and standard errors for the different crosses, sex and parity are presented in Tables 2, 3 and 4 at birth, weaning and 20 weeks of age respectively. There were significant differences between the various crosses, sexes and parity indicating that they exhibited different levels of performance in terms of body weight and morphometric traits. Among the crosses, LRxLW was significantly highest $(\mathrm{P}<0.05)$ for bodyweight at birth, weaning and 20 weeks of age, although the cross LRxIN and LWxLW were not significantly different from LRxLW at weaning. Apart from TL which was not significantly different between the crosses at 20 weeks of age, all the other morphometric traits showed significant difference $(\mathrm{P}<0.05)$ at birth, weaning and 20 weeks of age. Females were heavier than males at birth and weaning, but no significant differences for the morph metric traits recorded at all the ages measured. This is not in line with the typical sexual dimorphism expressed in most avian and mammalian species according to Ikeobi et al. (2005). This could be ascribed to more females farrowed compared to males. Parity 2 was significantly higher than parity 1 for morphometric traits - HG and HW at birth, while parity 1 was significantly higher than parity 2 for EL and TL at weaning and EL only at 20 weeks of age. Previous work has demonstrated parity effects for numerous sow traits to increase as the number of parity increases. Baas et al. (1992) reported that the effects of parity on weaning weight increases initially and then decreases in subsequent parities. Similarly, the American National Swine Improvement Federation (1997) defined parity 4 as the parity in which sows peak most production traits before it declines.

Analysis of Variance for Diallel crosses

The analysis of variance tables for testing the significance of GCA, SCA and RE are summarized in Table 5. There was no significant GCA for BWT and all the morphometric traits measured at all the ages, implying the non importance of 
Table 2: The least square means and standard errors for body weight and linear body measurements at Birth

\begin{tabular}{|c|c|c|c|c|c|c|c|c|c|c|}
\hline & \multicolumn{2}{|c|}{ Source $^{1}$} & \multicolumn{8}{|c|}{ Traits $^{2}$} \\
\hline & Sire & Dam & BWT & EL & $\mathrm{TL}$ & HG & $\mathrm{SC}$ & SL & HW & BL \\
\hline & Lines & Lines & (g) & (cm) & $(\mathrm{cm})$ & $(\mathrm{cm})$ & $(\mathrm{cm})$ & $(\mathrm{cm})$ & $(\mathrm{cm})$ & $(\mathrm{cm})$ \\
\hline \multirow{9}{*}{ Crosses } & IN & IN & $0.92 \pm 0.05^{\mathrm{d}}$ & $4.90 \pm 0.28^{b c}$ & $7.50 \pm 0.17^{\mathrm{a}}$ & $23.40 \pm 0.22^{a b}$ & $7.50 \pm 0.22^{\mathrm{e}}$ & $4.80 \pm 0.13^{\mathrm{a}}$ & $17.20 \pm 0.25^{c}$ & $18.90 \pm 0.43^{\mathrm{d}}$ \\
\hline & & LR & $1.37 \pm 0.07^{\mathrm{c}}$ & $4.36 \pm 0.20^{\mathrm{c}}$ & $3.82 \pm 0.50$ & $18.45 \pm 1.31^{\mathrm{c}}$ & $12.55 \pm 0.68^{\mathrm{cd}}$ & $3.18 \pm 0.12^{\mathrm{cd}}$ & $17.36 \pm 0.66^{\mathrm{c}}$ & $30.64 \pm 1.58^{b c}$ \\
\hline & & LW & $1.61 \pm 0.16^{\mathrm{b}}$ & $4.33 \pm 0.24^{\mathrm{c}}$ & $3.67 \pm 0.44^{\mathrm{c}}$ & $17.11 \pm 0.96^{\mathrm{c}}$ & $13.44 \pm 0.18^{b c}$ & $3.44 \pm 0.18^{\mathrm{cd}}$ & $16.67 \pm 0.41^{\mathrm{c}}$ & $26.56 \pm 0.77^{\mathrm{c}}$ \\
\hline & LR & IN & $1.72 \pm 0.08$ & $4.18 \pm 0.18^{\mathrm{c}}$ & $5.09 \pm 0.34^{\mathrm{b}}$ & $17.27 \pm 0.51{ }^{\mathrm{c}}$ & $11.18 \pm 0.60^{\mathrm{d}}$ & $3 \pm 0{ }^{\mathrm{d}}$ & $17.18 \pm 0.33^{\mathrm{c}}$ & $35.18 \pm 0.58^{\mathrm{a}}$ \\
\hline & & LR & $0.93 \pm 0.08{ }^{\mathrm{a}}$ & $5.42 \pm 0.27$ & $6.63 \pm 0.31^{\mathrm{a}}$ & $23.75 \pm 1.71^{\text {ab }}$ & $15.50 \pm 0.47^{\mathrm{a}}$ & $5.04 \pm 0.13{ }^{\mathrm{a}}$ & $20.25 \pm 0.74^{\mathrm{b}}$ & $27.58 \pm 1.02^{\mathrm{c}}$ \\
\hline & & LW & $2.10 \pm 0.09^{\mathrm{a}}$ & $4.50 \pm 0.19^{\mathrm{c}}$ & $4.50 \pm 0.52^{b c}$ & $22.64 \pm 1.29^{\mathrm{ab}}$ & $14.79 \pm 0.50 \mathrm{ab}$ & $4.25 \pm 0.17^{\mathrm{b}}$ & $19.43 \pm 0.45^{\mathrm{b}}$ & $29.64 \pm 1.35^{b c}$ \\
\hline & LW & IN & $1.09 \pm 0.04{ }^{\mathrm{d}}$ & $3.25 \pm 0.13{ }_{\mathrm{bc}}^{\mathrm{d}}$ & $4.08 \pm 0.39$ & $18.58 \pm 0.65^{\mathrm{c}}$ & $12.92 \pm 0.96^{\mathrm{cd}}$ & $3.75 \pm 0.13 \mathrm{bc}$ & $15.67 \pm 0.53{ }^{\mathrm{c}}$ & $29.92 \pm 2.02^{\mathrm{c}}$ \\
\hline & & LR & $1.67 \pm 0.12{ }^{\mathrm{b}}$ & $4.67 \pm 0.13{ }^{b c}$ & $3.53 \pm 0.24{ }^{\mathrm{c}}$ & $22.0 \pm 0.58^{\mathrm{b}}$ & $15.0 \pm 0.45^{\mathrm{ab}}$ & $3.47 \pm 0.13^{b c}$ & $19.93 \pm 0.56^{\mathrm{b}}$ & $32.53 \pm 0.82^{\mathrm{ab}}$ \\
\hline & & LW & $0.98 \pm 0.04{ }_{b}^{\mathrm{d}}$ & $5.73 \pm 0.23^{\mathrm{a}}$ & $7.46 \pm 0.31^{\mathrm{a}}$ & $25.31 \pm 0.97^{\mathrm{a}}$ & $16.23 \pm 0.48^{\mathrm{a}}$ & $4.89 \pm 0.19^{\mathrm{a}}$ & $21.96 \pm 0.76^{\mathrm{a}}$ & $29.12 \pm 1.05^{\mathrm{bc}}$ \\
\hline \multirow[t]{2}{*}{ Sex } & SEX 1 & Male & $1.25 \pm 0.06^{\mathrm{b}}$ & $4.75 \pm 0.13$ & $5.32 \pm 0.25$ & $21.96 \pm 0.60$ & $14.16 \pm 0.38$ & $4.14 \pm 0.11$ & $19.24 \pm 0.39$ & $28.35 \pm 0.69$ \\
\hline & SEX 2 & Female & $1.38 \pm 0.07^{\mathrm{a}}$ & $4.84 \pm 0.16$ & $5.66 \pm 0.27$ & $21.66 \pm 0.62$ & $13.67 \pm 0.43$ & $4.22 \pm 0.13$ & $18.91 \pm 0.44$ & $29.20 \pm 0.74$ \\
\hline \multirow[t]{2}{*}{ Parity } & Parity 1 & parity 1 & $1.35 \pm 0.06$ & $4.69 \pm 0.13$ & $5.60 \pm 0.26$ & $20.73 \pm 0.49^{\mathrm{b}}$ & $13.17 \pm 0.36$ & $4.17 \pm 0.12$ & $18.38 \pm 0.32^{\mathrm{b}}$ & $28.16 \pm 0.69$ \\
\hline & Parity 2 & parity 2 & $1.27 \pm 0.06$ & $4.88 \pm 0.15$ & $5.38 \pm 0.26$ & $22.79 \pm 0.67^{\mathrm{a}}$ & $14.12 \pm 0.44$ & $4.19 \pm 0.12$ & $19.71 \pm 0.46^{\mathrm{a}}$ & $29.32 \pm 0.74$ \\
\hline
\end{tabular}

abcd means with different alphabets on the same column are significantly different $(\mathrm{P}<0.05)$

${ }^{1} \mathrm{IN}=$ Indigenous breed, LR = Landrace breed, LW = Large white

${ }^{2} \mathrm{BWT}=$ Body weight, $\mathrm{EL}=$ Ear length, $\mathrm{TL}=$ Tail length, $\mathrm{HG}=$ Heart girth, $\mathrm{SC}=$ Snout Circumference, $\mathrm{SL}=$ Snout length,

$\mathrm{HW}=$ Height at withers, $\mathrm{BL}=$ Body length 
Effect of genotype and parity on growth traits of diallel crossed indigenous and exotic pigs

Table 3: The least square means and standard errors for body weight and linear body measurements at Weaning

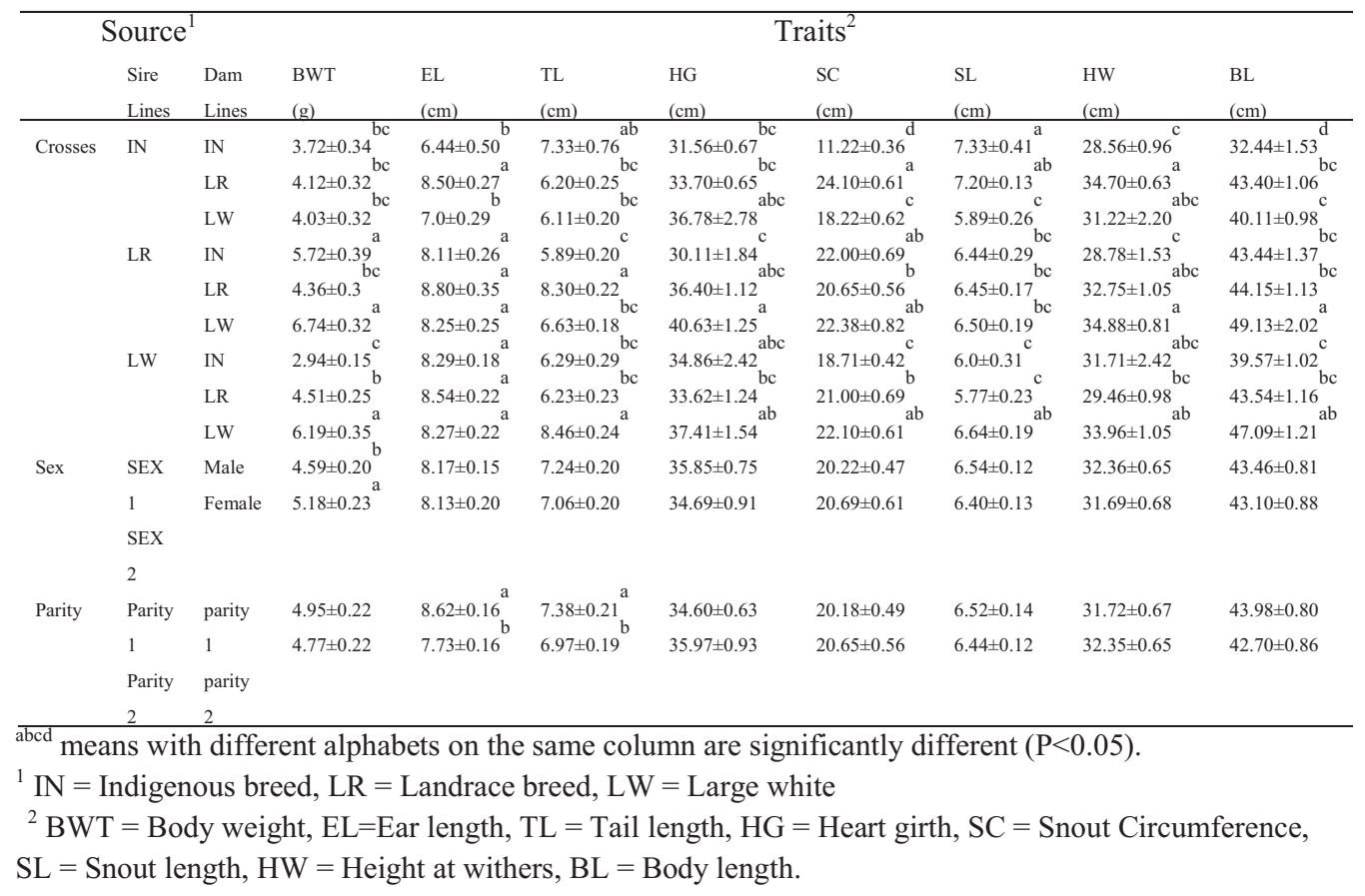

additive genetic effects for all the phenotypes of these traits measured. Meanwhile SCA was significant $(\mathrm{P}<0.01)$ for BWT and morphormetric traits measured at all the ages measured, indicating the importance of dominance. However, RE was significant $(\mathrm{P}<0.05)$ for BWT at birth and weaning, while at 20 weeks, it was significant $(\mathrm{P}<0.01)$ for $\mathrm{SC}$ and HW. In addition, $\mathrm{SC}$ and $\mathrm{HW}$ are influenced by maternal effects at 20 weeks of age as significant reciprocal effects are usually ascribed to maternal influence. This suggests a high maternal effect for BWT and morphometric traits measured at all the ages measured and the subsequent likelihood of sex-linkage due to the traits.

\section{General Combining Ability}

Estimates of GCA for all traits are shown in Tables 6, 7 and 8 for birth, weaning and 20 weeks of age respectively. The values of GCA for the IN genotype ranged from -2.05 for $\mathrm{BL}$ at 20 weeks to 0.81 for $\mathrm{HG}$ at weaning, while the LR genotype GCA ranged from 0.01 for TL at 20 weeks to 1.42 for $\mathrm{BL}$ at 20 weeks of age. The LW genotype GCA ranged from - 0.01 for BWT and EL at 20 weeks to 1.17 for BL at birth. The LR genotype exhibited the highest GCA (0.082) for BWT followed by LW (0.018) and IN (-0.096) at birth. Also, at weaning and 20 weeks of age, LR breed exhibited the highest GCA (0.4 \& 0.81$)$ respectively. Apart from BWT trait, the LR 
Okoro, Ogundu, Udedibie, Okoro, Ukwu and Ibe

Table 4: The least square means and standard errors for body weight and linear body measurements at 20 weeks of age

\begin{tabular}{|c|c|c|c|c|c|c|c|c|c|c|}
\hline \multicolumn{3}{|c|}{ Source $^{1}$} & \multicolumn{8}{|c|}{ Traits $^{2}$} \\
\hline & Sire & Dam & BWT & EL & $\mathrm{TL}$ & HG & $\mathrm{SC}$ & SL & HW & BL \\
\hline & Lines & Lines & (g) & $(\mathrm{cm})$ & (cm) & $(\mathrm{cm})$ & $(\mathrm{cm})$ & $(\mathrm{cm})$ & $(\mathrm{cm})$ & $(\mathrm{cm})$ \\
\hline \multirow[t]{9}{*}{ Crosses } & \multirow[t]{3}{*}{$\mathrm{IN}$} & IN & $8.24 \pm 0.60^{\mathrm{e}}$ & $8.22 \pm 0.57^{\mathrm{c}}$ & $8.56 \pm 0.82$ & $42.56 \pm 0.93^{\mathrm{c}}$ & $15.56 \pm 0.24^{\mathrm{d}}$ & $8.56 \pm 0.34^{\mathrm{b}}$ & $36.78 \pm 0.98^{\mathrm{c}}$ & $49.0 \pm 0.82^{\mathrm{c}}$ \\
\hline & & LR & $28.58 \pm 1.25$ & $10.0 \pm 0.27{ }^{b}$ & $9.38 \pm 0.26$ & $55.75 \pm 1.53^{\mathrm{a}}$ & $30.63 \pm 0.78^{a b}$ & $9.88 \pm 0.13^{\mathrm{a}}$ & $61.13 \pm 2.11^{\mathrm{a}}$ & $66.38 \pm 2.60{ }^{\mathrm{a}}$ \\
\hline & & LW & $21.88 \pm 0.99{ }^{\mathrm{a}}$ & $9.44 \pm 0.18{ }^{\mathrm{b}}$ & $9.11 \pm 0.26$ & $53.33 \pm 2.31^{\mathrm{ab}}$ & $22.56 \pm 0.56{ }^{\mathrm{c}}$ & $8.89 \pm 0.20^{\mathrm{b}}$ & $46.56 \pm 2.52^{b}$ & $58.67 \pm 1.53^{\mathrm{b}}$ \\
\hline & \multirow[t]{3}{*}{ LR } & IN & $24.79 \pm 1.82{ }_{\mathrm{dc}}$ & $9.56 \pm 0.18^{\circ}$ & $8.89 \pm 0.26$ & $47.22 \pm 2.60^{\mathrm{bc}}$ & $29.11 \pm 0.68^{\mathrm{ab}}$ & $9.78 \pm 0.15^{\mathrm{a}}$ & $43.11 \pm 1.57^{\mathrm{O}}$ & $68.78 \pm 2.25{ }^{\mathrm{a}}$ \\
\hline & & LR & $22.83 \pm 1.06^{\mathrm{dc}}$ & $11.75 \pm 0.29^{\mathrm{a}}$ & $9.45 \pm 0.28$ & $43.10 \pm 1.61{ }^{\mathrm{c}}$ & $24.15 \pm 0.91^{\mathrm{c}}$ & $8.50 \pm 0.19^{\mathrm{b}}$ & $41.0 \pm 1.46^{\mathrm{bc}}$ & $56.95 \pm 0.66^{\mathrm{b}}$ \\
\hline & & $\mathrm{LW}$ & $30.58 \pm 0.67^{\mathrm{a}}$ & $9.75 \pm 0.16^{\mathrm{b}}$ & $9.38 \pm 0.18$ & $52.75 \pm 1.25^{\mathrm{ab}}$ & $31.88 \pm 0.91^{\mathrm{a}}$ & $10.0 \pm 0.19^{\mathrm{a}}$ & $46.75 \pm 1.15^{\mathrm{b}}$ & $69.50 \pm 2.20{ }^{\mathrm{a}}$ \\
\hline & \multirow[t]{3}{*}{ LW } & IN & $26.57 \pm 2.83$ & $10.29 \pm 0.29^{\circ}$ & $8.86 \pm 0.14$ & $45.71 \pm 3.21$ & $21.43 \pm 0.69$ & $8.57 \pm 0.29^{\mathrm{D}}$ & $44.71 \pm 3.47^{\circ}$ & $57.14 \pm 1.22^{\mathrm{D}}$ \\
\hline & & LR & $27.49 \pm 1.59$ bcd & $9.54 \pm 0.18^{\circ}$ & $8.85 \pm 0.15$ & $44.85 \pm 1.56$ & $27.85 \pm 1.02^{\circ}$ & $9.15 \pm 0.29 \mathrm{ab}$ & $42.69 \pm 0.84{ }^{\mathrm{b}}$ & $60.15 \pm 1.44$ \\
\hline & & LW & $23.75 \pm 0.85$ & $12.27 \pm 0.30^{\mathrm{a}}$ & $9.45 \pm 0.24$ & $49.32 \pm 1.26$ & $27.91 \pm 0.86^{\circ}$ & $9.36 \pm 0.12^{\mathrm{ab}}$ & $44.36 \pm 0.91^{\mathrm{b}}$ & $65.41 \pm 1.53^{\mathrm{a}}$ \\
\hline \multirow[t]{4}{*}{ Sex } & SEX & Male & $23.29 \pm 0.89$ & $10.58 \pm 0.22$ & $9.25 \pm 0.14$ & $48.11 \pm 0.99$ & $25.44 \pm 0.69$ & $9.04 \pm 0.13$ & $44.67 \pm 0.99$ & $60.91 \pm 1.01$ \\
\hline & 1 & Female & $24.22 \pm 1.02$ & $10.44 \pm 0.25$ & $9.08 \pm 0.18$ & $47.17 \pm 1.03$ & $26.33 \pm 0.79$ & $9.25 \pm 0.12$ & $44.15 \pm 1.11$ & $61.73 \pm 1.81$ \\
\hline & \multicolumn{10}{|l|}{ SEX } \\
\hline & \multicolumn{10}{|l|}{2} \\
\hline \multirow[t]{4}{*}{ Parity } & Parity & parity 1 & $24.22 \pm 0.93$ & $10.88 \pm 0.24^{\mathrm{a}}$ & $9.28 \pm 0.13$ & $46.62 \pm 1.11$ & $25.28 \pm 0.66$ & $9.10 \pm 0.12$ & $43.74 \pm 1.06$ & $61.62 \pm 1.11$ \\
\hline & 1 & parity 2 & $23.25 \pm 0.98$ & $10.18 \pm 0.22^{\mathrm{b}}$ & $9.07 \pm 0.17$ & $48.64 \pm 0.89$ & $26.36 \pm 0.79$ & $9.16 \pm 0.13$ & $45.05 \pm 1.03$ & $60.98 \pm 1.07$ \\
\hline & \multicolumn{10}{|l|}{ Parity } \\
\hline & 2 & & & & & & & & & \\
\hline
\end{tabular}

abcd means with different alphabets on the same column are significantly different $(\mathrm{P}<0.05)$.

${ }^{1} \mathrm{IN}=$ Indigenous breed, LR $=$ Landrace breed, LW $=$ Large white

${ }^{2}$ BWT $=$ Body weight, EL=Ear length, $\mathrm{TL}=$ Tail length, $\mathrm{HG}=$ Heart girth, $\mathrm{SC}=$ Snout Circumference, $\mathrm{SL}$

$=$ Snout length, $\mathrm{HW}=$ Height at withers, $\mathrm{BL}=$ Body length .

genotype also exhibited the highest GCA in the morphometric traits - EL and SL at birth, weaning and 20 weeks of age. Previous study by Okoro et al. (2012a) reported non significant GCA effect for BWT and 5 morphometric traits at 12 weeks of age in a diallel cross involving locally adapted turkeys. However, Nestor et al. (2005) reported a significant additive genetic effect for BrWt, SL, walking ability and BWT at 8,16 and 20 weeks of age in crosses of commercial turkeys. Berenskin and Hetzer (1986) reported a significant $(\mathrm{P}<0.1$ to $\mathrm{P}<0.01)$ GCA effects for body weight at birth, 56 days and 140 days of age and non at 21 days of age for barrows in a diallel crosses involving High fat and Low fat lines of swine, while non $(\mathrm{P}>0.05$ to $\mathrm{P}>0.1)$ was recorded for the gilts. Specific Combining Ability SCA was significant $(\mathrm{P}<0.01)$ for all the traits measured (BWT and morphometric traits) at birth, weaning and 20 weeks of age. At birth, the cross LRxLW exhibited the highest SCA for all the traits measured except TL and BL while INxLW and INxLR had the least values except for INxLW which recorded the highest for TL and BL traits. At weaning, the LRxLW cross also reported the highest SCA for all the traits except SC and SL, while at 20 weeks, the LRxLW cross also reported the highest SCA for all the traits except EL, HG and SC traits where INxLR cross was higher. The 
Effect of genotype and parity on growth traits of diallel crossed indigenous and exotic pigs

Table 5: Summary of the analysis of variance for the combining abilities at Birth, Weaning and 20 weeks of age.

\begin{tabular}{|c|c|c|c|c|c|c|c|c|c|c|}
\hline \multirow{2}{*}{ Traits ${ }^{1}$} & \multirow{2}{*}{ Effects $^{2}$} & \multicolumn{3}{|c|}{ BIRTH } & \multicolumn{3}{|c|}{ WEANING } & \multicolumn{3}{|c|}{20 WEEKS } \\
\hline & & MS & $99 \%$ & $95 \%$ & MS & $99 \%$ & $95 \%$ & MS & $99 \%$ & $95 \%$ \\
\hline \multirow[t]{4}{*}{ BWT } & GCA & 0.049 & & & 0.795 & & & 3.852 & & \\
\hline & SCA & 8.198 & $* *$ & $*$ & 54.830 & $* *$ & $*$ & $2,108.056$ & $* *$ & $*$ \\
\hline & RE & 0.387 & & * & 5.805 & $* *$ & * & 30.56 & & \\
\hline & Error & 0.104 & & & 1.367 & & & 20.127 & & \\
\hline \multirow[t]{4}{*}{ EL } & GCA & 0.106 & & & 0.112 & & & 0.009 & & \\
\hline & SCA & 32.267 & $* *$ & $*$ & 158.89 & $* *$ & $*$ & 202.859 & $* *$ & * \\
\hline & $\mathrm{RE}$ & 0.823 & & & 1.26 & & & 0.634 & & \\
\hline & Error & 0.869 & & & 1.006 & & & 1.125 & & \\
\hline \multirow[t]{4}{*}{ TL } & GCA & 0.06 & & & 0.025 & & & 0.004 & & \\
\hline & SCA & 11.45 & $* *$ & $*$ & 67.0 & $* *$ & $*$ & 190.795 & $* *$ & $*$ \\
\hline & $\mathrm{RE}$ & 1.82 & & & 0.19 & & & 0.387 & & \\
\hline & Error & 2.092 & & & 1.108 & & & 1.297 & & \\
\hline \multirow[t]{4}{*}{ HG } & GCA & 4.395 & & & 4.91 & & & 1.29 & & \\
\hline & SCA & 711.93 & $* *$ & $*$ & $2,873.63$ & $* *$ & $*$ & $6,313.491$ & $* *$ & $*$ \\
\hline & $\mathrm{RE}$ & 2.65 & & & 43.808 & & & 128.833 & & \\
\hline & Error & 15.69 & & & 30.548 & & & 38.584 & & \\
\hline \multirow[t]{4}{*}{$\mathrm{SC}$} & GCA & 1.54 & & & 3.691 & & & 13.77 & & \\
\hline & SCA & 431.04 & $* *$ & $*$ & $1,189.443$ & $* *$ & * & $2,081.195$ & $* *$ & $*$ \\
\hline & $\mathrm{RE}$ & 1.454 & & & 4.363 & & & 13.197 & $* *$ & \\
\hline & Error & 5.44 & & & 5.316 & & & 10.287 & & \\
\hline \multirow[t]{4}{*}{ SL } & GCA & 0.1 & & & 0.142 & & & 0.221 & & \\
\hline & SCA & 19.14 & $* *$ & $*$ & 87.200 & $* *$ & $*$ & 217.392 & $* *$ & $*$ \\
\hline & $\mathrm{RE}$ & 0.67 & & & 0.747 & & & 0.684 & & \\
\hline & Error & 0.41 & & & 0.683 & & & 0.571 & & \\
\hline \multirow[t]{4}{*}{ HW } & GCA & 2.155 & & & 0.0835 & & & 10.843 & & \\
\hline & SCA & 671.64 & $* *$ & $*$ & $2,361.385$ & $* *$ & $*$ & $5,970.551$ & $* *$ & $*$ \\
\hline & $\mathrm{RE}$ & 0.858 & & & 43.077 & & & 229.631 & $* *$ & $*$ \\
\hline & Error & 6.924 & & & 20.299 & & & 29.787 & & \\
\hline \multirow[t]{4}{*}{ BL } & GCA & 6.706 & & & 7.046 & & & 16.557 & & \\
\hline & SCA & 2480.24 & $* *$ & $*$ & $4,574.757$ & $* *$ & $*$ & $10,299.14$ & $* *$ & $*$ \\
\hline & $\mathrm{RE}$ & 19.432 & & & 21.007 & & & 63.63 & & \\
\hline & Error & 21.715 & 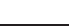 & 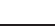 & 20.519 & 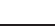 & & 28.39 & 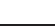 & \\
\hline
\end{tabular}

significant SCA is an indication of nonadditive gene action for these traits which is thought to reflect dominance or epistatic gene action or both. This means that BWT and all the morphometric traits can be improved genetically through the appropriate crossing, utilizing heterosis. The results indicate that the LR genotype performed generally well in crosses with the other exotic genotype - LW. Cross performance was poor for INxLW and INxLR suggesting less importance of nonadditive gene action compared to LRxLW cross, although there was significant SCA effect. In some studies, it was suggested that non-additive genetic variations is an 
important source of variation in growth traits, particularly in offspring of crosses of lines differing greatly in growth rate and body conformation (Bereskin and Hetzer, 1986). Bereskin and Hetzer (1986) reported a significant SCA effect at 21 days, 56 days and age in days at $79.4 \mathrm{~kg}$ (AGE) for gilts in a diallel crosses involving High fat and Low fat lines of swine, while no significance was attained with barrows. Emmerson et al. (1991) observed significant heterosis for BWT at older ages and shank length in $\mathrm{F}_{1}$ reciprocal crosses of an experimental line selected long term for increased 16-week body weight and an older commercial sire line in turkeys. However, Eisen et al.

Table 6: Estimates of General Combining ability, Specific Combining ability and reciprocal effects of growth traits of crosses of pigs at birth

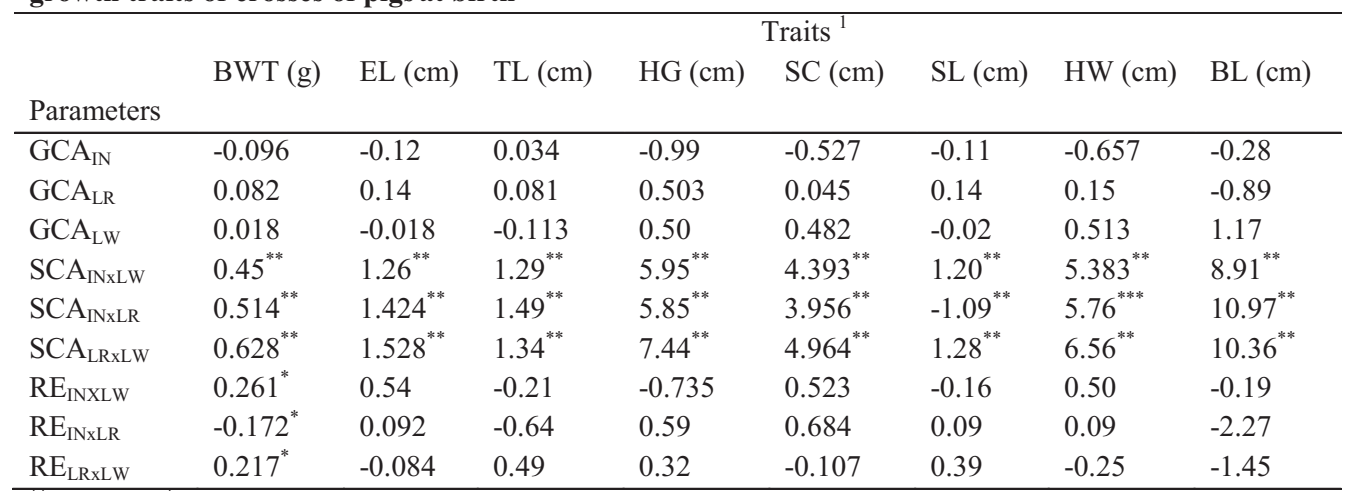

${ }^{* *}=\mathrm{P}<0.01,{ }^{*}=\mathrm{P}<0.05$ for $\mathrm{H}_{0}$ : parameters $=0$

${ }^{1} \mathrm{BWT}=$ Day 1 Body weight, $\mathrm{EL}=$ Ear length, $\mathrm{TL}=$ Tail length, $\mathrm{HG}=$ Heart girth, $\mathrm{SC}=$ Snout

Circumference, $\mathrm{SL}=$ Snout length, $\mathrm{HW}=$ Height at withers, $\mathrm{BL}=$ Body length.

Table 7: Estimates of General Combining ability, Specific Combining ability and reciprocal effects of growth traits of crosses of pigs at weaning

\begin{tabular}{|c|c|c|c|c|c|c|c|c|}
\hline Parameters & $\begin{array}{l}\text { BWT } \\
\text { (g) }\end{array}$ & $\begin{array}{l}\text { EL } \\
(\mathrm{cm})\end{array}$ & $\mathrm{TL}(\mathrm{cm})$ & $\mathrm{HG}(\mathrm{cm})$ & $\begin{array}{l}\text { Traits } \\
\text { SC (cm) }\end{array}$ & $\mathrm{SL}(\mathrm{cm})$ & $\begin{array}{l}\text { HW } \\
(\mathrm{cm})\end{array}$ & $\mathrm{BL}(\mathrm{cm})$ \\
\hline $\mathrm{GCA}_{\mathrm{IN}}$ & -0.32 & -0.093 & -0.07 & 0.81 & -0.21 & 0.06 & -0.13 & -1.05 \\
\hline $\mathrm{GCA}_{\mathrm{LR}}$ & 0.40 & 0.16 & 0.01 & -0.29 & 0.87 & 0.12 & 0.11 & 1.12 \\
\hline $\mathrm{GCA}_{\mathrm{LW}}$ & -0.08 & -0.06 & 0.06 & 1.01 & -0.66 & -0.17 & -0.98 & -0.08 \\
\hline $\mathrm{SCA}_{\mathrm{INxLW}}$ & $1.16^{* *}$ & $2.55^{* *}$ & $2.07^{* *}$ & $11.94^{* *}$ & $6.16^{* *}$ & $1.98^{* *}$ & $10.49^{* *}$ & $13.28^{* *}$ \\
\hline$S C A_{I N \times L R}$ & $1.64^{* *}$ & $2.77^{* *}$ & $2.02^{* *}$ & $10.64^{* *}$ & $7.68^{* *}$ & $2.27^{* *}$ & $10.58^{* *}$ & $14.47^{* *}$ \\
\hline $\mathrm{SCA}_{\mathrm{LRxLW}}$ & $1.90^{* *}$ & $2.80^{* *}$ & $2.17^{* *}$ & $12.37^{* *}$ & $7.23^{* *}$ & $2.05^{* *}$ & $10.72^{* *}$ & $15.44^{* *}$ \\
\hline $\mathrm{RE}_{\text {INXLW }}$ & $0.55^{* *}$ & 0.643 & -0.09 & 0.96 & -0.25 & -0.06 & -0.25 & 0.27 \\
\hline$R E_{I N x L R}$ & $-0.80^{* *}$ & 0.19 & 0.16 & 1.79 & 1.05 & 0.38 & 2.96 & -0.02 \\
\hline $\mathrm{RE}_{\mathrm{LRxLW}}$ & $1.11^{* *}$ & -0.14 & 0.20 & 3.51 & 0.69 & 0.37 & 2.71 & 2.79 \\
\hline
\end{tabular}

${ }^{* *}=\mathrm{P}<0.01,{ }^{*}=\mathrm{P}<0.05$ for $\mathrm{H}_{0}$ : parameters $=0$

${ }^{1} \mathrm{BWT}=8$-weeks Body weight, $\mathrm{EL}=$ Ear length, $\mathrm{TL}=$ Tail length, $\mathrm{HG}=$ Heart girth, $\mathrm{SC}=$ Snout Circumference, $\mathrm{SL}=$ Snout length, $\mathrm{HW}=$ Height at withers, $\mathrm{BL}=$ Body length. 
(1983) suggested that data used to provide genetic interpretation of dominance effects can be further clarified by employing a reparameterized model that provides joint estimates of heterosis and combining ability as opposed to specific heterosis and SCA.Reciprocal Effect

There were significant $\mathrm{RE}(\mathrm{P}<0.05$ to $\mathrm{P}<0.01$ ) in BWT at birth and weaning, as well as for morphometric traits - HW and SC $(\mathrm{P}<0.01)$ at 20 weeks of age. These implied that there were sex-linked or maternal effects exhibited by the various crosses for the traits BWT, HW and SC at the identified ages. Nestor et al. (2005) reported a significant RE for SL in male and female turkeys in a commercial sire line and a line selected for long term increased 16week body weight using orthogonal contrasts. However, Silva et al. (1996), using Griffing's (1956) method, estimated the maternal and reciprocal effects on bodyweight at birth, 21, 35, and 77 days in crosses involving Duroc, Landrace, Yorkshire and Large White and reported a significant maternal effect at birth, 21 days and 35 days of age and no significant reciprocal effect at these ages. Iraqi et al. (2007) reported significant reciprocal, maternal and sex-linked effects on growth traits of crosses involving four breeds of chicken. Ibe et al. (2005) also reported no significant reciprocal effects on bodyweight and linear body measurements in rabbits.

\section{Conclusion}

The lack of significant GCA implied that there were very small differences in the effects of additive genes for BWT, EL, TL, $\mathrm{HG}, \mathrm{SC}, \mathrm{SL}, \mathrm{HW}$ and BL between the Indigenous, Large white and Landrace genotypes of pigs. Maternal and sex-linked effects can explain differences in the

Table 8: Estimates of General Combining ability, Specific Combining ability and reciprocal effects growth traits of crosses of pigs at 20 weeks of age.

\begin{tabular}{|c|c|c|c|c|c|c|c|c|}
\hline Parameters & $\begin{array}{l}\text { BWT } \\
(\mathrm{g})\end{array}$ & $\mathrm{EL}(\mathrm{cm})$ & TL (cm) & $\mathrm{HG}(\mathrm{cm})$ & $\begin{array}{l}\text { Traits }^{1} \\
\mathrm{SC}(\mathrm{cm})\end{array}$ & $\mathrm{SL}(\mathrm{cm})$ & $\begin{array}{l}\text { HW } \\
(\mathrm{cm})\end{array}$ & $\mathrm{BL}(\mathrm{cm})$ \\
\hline $\mathrm{GCA}_{\mathrm{IN}}$ & -0.79 & 0.04 & -0.05 & 0.38 & -0.87 & 0.76 & -1.11 & -2.05 \\
\hline $\mathrm{GCA}_{\mathrm{LR}}$ & 0.81 & -0.03 & -0.01 & 0.14 & 1.75 & 1.02 & 0.12 & 1.42 \\
\hline $\mathrm{GCA}_{\mathrm{LW}}$ & -0.01 & -0.01 & -0.06 & -0.57 & -0.88 & -0.57 & -0.36 & -0.38 \\
\hline $\mathrm{SCA}_{\mathrm{INxLW}}$ & $8.08^{* *}$ & $3.29^{* *}$ & $2.99^{* *}$ & $16.51^{* *}$ & $7.33^{* *}$ & $1.66^{* *}$ & $11.59^{* *}$ & $15.22^{* *}$ \\
\hline $\mathrm{SCA}_{\mathrm{INxLR}}$ & $8.92^{* *}$ & $3.26^{* *}$ & $3.04^{* *}$ & $17.16^{* *}$ & $9.96^{* *}$ & $1.98^{* *}$ & $9.37^{* *}$ & $13.71^{* *}$ \\
\hline $\mathrm{SCA}_{\mathrm{LRxLW}}$ & $9.68^{* *}$ & $3.22^{* *}$ & $3.04^{* *}$ & $16.27^{* *}$ & $9.95^{* *}$ & $2.11^{* *}$ & $14.76^{* *}$ & $16.23^{* *}$ \\
\hline $\mathrm{RE}_{\mathrm{INXLW}}$ & -2.34 & -0.42 & 0.13 & 3.81 & $0.56^{* *}$ & -0.19 & $-0.75^{* *}$ & 0.54 \\
\hline $\mathrm{RE}_{\mathrm{INxLR}}$ & 1.89 & 0.22 & 0.24 & 4.26 & $0.76^{* *}$ & -0.46 & $3.76^{* *}$ & -0.32 \\
\hline $\mathrm{RE}_{\mathrm{LRxLW}}$ & 1.55 & 0.11 & 0.26 & 3.95 & $2.01^{* *}$ & 0.55 & $1.91^{* *}$ & 2.82 \\
\hline
\end{tabular}


observed phenotype for BWT, HW and SC of the progenies at birth, weaning and 20 weeks of age due to significant RE effects. The significant SCA for all the traits measured points to the importance of nonadditive gene action for these traits; hence, improvement in these traits can be done by planned crossbreeding in order to exploit the existing heterosis.

\section{References}

Baas, T. J., Christian, L. L., and Rothchild, M. F., 1992. Heterosis and recombination effects in Hampshire and Landrace swine. I. Maternal traits. J. Anim. Sci. 70: 8998.

Bereskin, B. and Hetzer, H. O., 1986. Genetic and Maternal effects on pig weights, growth and probe backfat in Diallel crosses of High and Low-fat lines of swine. J. of Animal Science. 63: 395-408.

Buchanan, S. D., Luce, W. G. and Clutter, A. C., 2005. Swine breeding systems. Oklahoma Cooperative Extension Service ANSI-3603.

Carmon, J. L., 1976. Heterosis, Combining Ability, and Maternal Effects in Mice. Ga. Agric. Expt. Sta. Tech. Bul., N. S. 182.

Durrant, A., 1965. Analysis of reciprocal differences in diallel crosses. Heredity 20: 573-607.

Eisen, E. J., Bohren, B. B. and McKean, H. E., 1966. Sex Linked and Maternal effects in the diallel cross. Aust. J. Biol. Sci. 19: 1061-1071

Eisen, E. J., Horstgen-Schwark, G., Saxton, A. M. and Bandy, T. R., 1983. Genetic interpretation and analysis of diallel crosses with animals. Theor. Appl. Genet. 65: 17-
23.

Emmerson, D. A., Anthony N. B., and Nestor K. E., 1991. Genetics of growth and reproduction in the turkey. 11. Evidence of non-additive genetic variation. Poultry Science 70: 1081 1091.

Griffing, B., 1956. Concept of general and specific combining ability in relation to diallel crossing systems. Aust. J. Biol. Sci. 9: 465-493.

Ibe, S. N., 1998. An Introduction to Genetics and Animal Breeding. Longman Nigeria Plc.

Ibe, S. N., Obasi, V. N., Ojewola, G. S, and Nwachukwu, E. N., 2005. Heterosis and reciprocal effects for growth traits in crosses of New Zealand White, Dutch and Chinchilla breeds of rabbits. Nig. J. Anim. Prod. 32(2): $191-197$.

Ikeobi, C. O. N., Peters S. O. and Ebozoje M. O.,1995. Sexual dimorphism in two strains of broiler chicken. Nigerian Journal of Genetics 10: 16 22.

Iraqi, M. M, Afifi, E. A., El-labban, A. F. M., and Afran, M., 2007. Heterotic and genetic components in $4 \times 4$ diallel mating experiment for egg production traits in chickens. $4^{\text {th }}$ World's Poultry Conference 27-30 March 2007, Sharm El-Sheikh, Egypt.

Mather, K. and Jinks, J. L., 1982. Biometrical Genetics. Chapman and Hall, London.

National Swine Improvement Federation, 1997. Guidelines for Uniform Swine Improvement Programs. Washington D. C. USDA.

Nestor K. E., Anderson J. W. and Velleman S. G., 2005. Genetic variations in purelines and crosses of large-bodied turkey line. 3. Growth related measurements on live birds. 
Poultry Science 84: 1341 - 1346.

Obasi, V. N. and Ibe, S. N., 2008. Influence of additive and non-additive gene effects on body measurements in the domestic rabbits. Nigerian Journal of Animal Production 35(1): $1-8$.

Okoro, V. M. O, Ogundu U. E., Kadurumba O., Iloeje M. U., Okoro C. L., Nosike R. J., and S. N. Ibe, 2012a. Genetic variations in locally adapted turkeys. 1. Additive and nonadditive genetic effects on growth traits. Genomics and Quantitative Genetics 4: 1-7.

SAS, 1999. SAS Users Guide, Statistics Version 8, SAS Instutite Inc., Cary, North Carolina, USA.

Schneider, J. F., 1976. Heterosis, combining abilities and maternal ability estimated from single-crosses among four breeds of swine. Master's Thesis, Iowa State University, Ames, Iowa, pp. 107.

Siewerdt, F and Dionello N. J. L., 1991.
Comparison of egg production of three leghorn strains and their reciprocal crosses. Revista da Sociedad Brasileira de Zootecnia 19: 209-218.

Silva, M. A., Sancevero, A. B., Rafael, G. O., Antonio, L. G., Paulo, S. L. and Robert, A. A., 1996. Effect of type of cross on litter size and litter weight of purebred and crossbred swine. Brazilian Journal of Genetics 19 (2) 249-258.

Topham, P. B., 1966. Diallel analysis involving maternal and paternal interaction effects. Heredity 21: 665674.

Virk, D. S., Khehra, A. S., Virk, P. S. and Dhillon, B. S., 1985. Comparative genetic analysis of metric traits using diallel and factorial designs in bread wheat. Theor. Appl. Genet. 69: 325328.

Wearden, S., 1964. Alternative analyses of the diallel cross. Heredity 19: 669680 .

Received: $\boldsymbol{8}^{\text {th }}$ December, 2014 Accepted:22 ${ }^{\text {nd }}$ February, 2015 